\title{
Mosquito Biodiversity and Intensiveness in the Mountain and Beach Ecosystem of Luwu District
}

\author{
Suyanti $^{1 *}$, Hasanuddin Ishak ${ }^{1}$, Hasnawati Amqam ${ }^{1}$, Syamsuar Manyullei ${ }^{1}$, Rafael Djajakusli ${ }^{2}$ \\ ${ }^{\mathrm{T}}$ Departement of Environmental Health, Faculty of Public Health, Hasanuddin University, Indonesia \\ ${ }^{2}$ Department of occupational Health and Safety, Faculty of Public Health, Hasanuddin University, Indonesia
}

\section{*Corresponding Author}

Suyanti

\section{Article History}

Received: 19.09 .2020

Accepted: 09.10.2020

Published: 20.10.2020

\begin{abstract}
Mosquito are small insects, have three pairs of legs, two scaly wings, and a mouth (proboscis) to pierce and suck blood. Mosquito have various characteristics, especially in the morphology of the type of mosquito and their beneficial role for the ecosystem, namely as a food chain and their role that is detrimental to their host with their nature as a vector. This study aims to determine the biodiversity of mosquitoes and its prevalence in mountains ecosystems and beach in Luwu District. This type of research is a descriptive ecological study using an observational approach. The population and sample of the study were all mosquitoes and mosquitoes caught in the villages of Siteba, Limbong, Sangtandung as a mountains ecosystem and Bonepute, Temboe, Babang villages as a beach ecosystem in Luwu District. Data were obtained using the Animal Baited Trap, Human Landing Collection and Light Trap methods, then identification was carried out at the Entomology Laboratory, Faculty of Medicine, Hasanuddin University. The results of research in the mountain ecosystem of mosquito biodiversity obtained four genera, namely Anopheles, Aedes, Armigeres and Culex. Beach ecosystems are found in three genera Anopheles, Aedes and Culex. The density of mosquito in the mountains is more dominant, namely Cx.Tritaeniorhyncus, bait for people in the house 4.03 mosquito / person / night and bait people outside the house 4.39 mosquito / person / night. The more dominant biting beach ecosystem is Cx.Tritaeniorhynchus. Insider bait 3.47 mosquitos / person / night, bait outside the house 6.19 mosquito / person / night. The effectiveness of mountain traps obtained 14 species, beach 11 species. Further research is needed in depth information about the distribution patterns of mosquito fauna and their intensiveness in the mountains and beach ecosystems of Luwu District.
\end{abstract}

Keywords: Biodiversity, Intensiveness, Beach, Mountain Ecosystem.

\section{INTRODUCTION}

Mosquito are small insects, have three pairs of legs, two scaly wings, and a mouth (proboscis) to pierce and suck blood [11]. Mosquito are invertebrates (invertebrates), members of the order Diptera, family culicidae, and subfamilia culicinae. The culicidae or mosquito family is divided into 3 tribus, namely tribus anophelini (Anopheles), tribus culicini (Culex, Aedes, Mansonia) and tribus toxorhynchitini (Toxorhynchites) [2]. All over the world, these mosquito are widespread from arctic to tropical areas, can be found at an altitude of 5,000 meters above sea level and at a depth of 1,500 meters below ground level or in mining areas [20]. Mosquito have various characteristics that indicate characteristics, especially in the morphology of various types of mosquito and their beneficial roles for the ecosystem, namely as a food chain and their detrimental role for their hosts with their nature as vectors [17].

Mosquito play a negative role as disease-carrying vectors for their host by being a vector that transmits disease outbreaks because mosquito has a high degree of interaction with humans. From the 17th century to the early 20 th century, it was noted that diseases transmitted by mosquitoes or vector insects were more common than other diseases [5]. Correct morphological identification can be useful to determine the character and number of species so description of diversity in an area and efforts in handling and controlling the spread of mosquitoes in an area [11]. Apart from being a constituent component of the ecosystem, mosquitoes are also vectors of diseases such as dengue fever, yellow fever,

Copyright (C) 2020 The Author(s): This is an open-access article distributed under the terms of the Creative Commons Attribution 4.0 International License (CC BY-NC 4.0) which permits unrestricted use, distribution, and reproduction in any medium for non-commercial use provided the original author and source are credited. 
chikungunya, and encephalitis. Mosquito can live in various types of environment both in rural and urban areas. In maintaining the balance of the ecosystem, mosquito populations in nature are regulated by biotic factors (predators, parasites) and abiotic factors (temperature, rainfall, and climate) [5].

Mosquito as vectors of disease can interfere with human life. Apart from bites and buzzing, its role is as a carrier vector for various kinds of parasites that can cause disease in humans and animals [3]. Mosquito can live up to 4200 meters above sea level and up to 115 meters below sea level. The number of species in the tropics is more than in cold regions such as the south pole, the number of known mosquito species is approximately 2400 [9].

Some of the factors that can influence mosquito density are human behavior factors, environmental factors, socio-culture, and health service factors [6]. One of the most influential factors on mosquito intensiveness is environmental factors, where the environment is a place between disease agents and hosts. John Gordon's opinion when the environment undergoes a significant shift or change, resulting in vulnerability to hosts and an increase in population and an increase in the virulence of disease agents [15].

The high population density of mosquito can increase contact vectors that are infective to humans. Air temperature itself is part of the environment arising from the interaction of the ecosystem's abiotic parameters. Conditions of temperature and humidity can have a very strong influence on the activities of the survival of living things [4]. The impact that is generally faced in the health sector is a large population with a fairly high growth rate and uneven population distribution, low educational and socio-economic levels [1]. On the other hand, things like this can cause an inadequate physical and biological environment, allowing the proliferation of disease vectors [16]. In order to achieve the quality and quantity of a clean and healthy environment and to achieve an optimal degree of public health as an element of the general agreement of the national goals, disease vector control is very necessary [21].

Research conducted on mosquito fauna around cages in North Sumatra, there were 14 species caught and the most caught were Culex tritaeniorhynchus, Culex vishnui, and Culex fuscocephalus [8]. The aim of this initial treatment is that it is necessary to extract information on the diversity of fauna species of mosquito found in the area, because mosquito are vectors of disease. To help identify the fauna of mosquito species, the authors took the initiative to create a mosquito catching program using the Human Landing Collection (HLC) method or bait people, namely catching mosquito while sucking blood, catching mosquito by installing Animal Baited Trap and catching Light Trap mosquito in the ecosystem in Luwu District.

\section{Materials ANd Methods \\ Location and research design}

This research was conducted in a mountainous ecosystem located in the North Walenrang District, precisely in the villages of Siteba, Limbong and Sangtandung. The coastal ecosystem in South Larompong Sub-District, precisely in Bonepute Village, Tembo'e Village and Babang, Luwu District, South Sulawesi. The research was conducted from March to May 2020. This type of research is descriptive observational research.

\section{Population and sample}

The population in this study was all mosquitos in Siteba, Limbong and Sangtandung Village, North Walenrang Sub-District as a mountain ecosystem and all mosquitos in Bonepute Village, Tembo'e Village, Babang Village, and South Larompong Sub-District as a coastal ecosystem in Luwu District. The number of samples was mosquito caught in Siteba Village, Limbong Village, Sangtandung Village, North Walenrang Sub-District and mosquito caught in Bonepute Village, Tembo'e Village and Babang Village, South Larompong Sub-District, Luwu District.

\section{Data Collection}

The data collection methods used in this study were Animal trap, Human landing collection and Light trap methods, and through the identification of mosquito samples carried out at the Entomology Laboratory, Faculty of Medicine, Hasanuddin University.

\section{Data Analysis}

The data analysis used in this research is descriptive in terms of tables and narratives to determine the proportion of each variable.

\section{RESULTS}

Differences in Mosquito Biodiversity in Mountain Ecosystems and Beach Ecosystems 
Table-1: Percentage of differences in Mosquito Biodiversity in the Mountain and Beach Ecosystems of Luwu District in 2020

\begin{tabular}{|c|c|c|c|c|}
\hline \multirow{2}{*}{ Genus } & \multicolumn{5}{|c|}{ Mountain Ecosystem } \\
\cline { 2 - 5 } & Siteba (\%) & Limbong (\%) & Sangtandung (\%) & Total (\%) \\
\hline Anopheles & 12.47 & 24.31 & 63.21 & 10.81 \\
\hline Aedes & 0 & 88.88 & 11.11 & 0.41 \\
\hline Armigeres & 0,05 & 0 & 0 & 0.02 \\
\hline Culex & 43.63 & 41.21 & 15.15 & 88.74 \\
\hline Total & 40.09 & 39.56 & 20.33 & 26.89 \\
\hline \multirow{2}{*}{ Genus } & \multicolumn{5}{|c|}{ Beach Ecosystem } \\
\cline { 2 - 5 } & Bonepute (\%) & Temboe (\%) & Babang (\%) & Total (\%) \\
\hline Anopheles & 13.54 & 48.43 & 38.02 & 2.77 \\
\hline Aedes & 39.28 & 0,033 & 35.71 & 0.4 \\
\hline Armigeres & 0 & 0 & 0 & 0 \\
\hline Culex & 41,85 & 29.88 & 28.25 & 96.77 \\
\hline Total & 41,05 & 30,38 & 28,58 & 42,54 \\
\hline
\end{tabular}

Table 1 show that in the mountains ecosystem four genera were obtained, namely Anopheles, Aedes, Armigeres, Culex. Meanwhile, in the beach ecosystem, three genera of Anopheles, Aedes and Culex were obtained. Culex is mostly found in mountains and beach ecosystems. The highest in the mountain ecosystem was in the village of Siteba at $43.63 \%$ and the highest in the coastal ecosystem was in the village of Bonepute at $41.05 \%$. Armigeres are found in the mountains ecosystem of Siteba Village, while in the beach ecosystem there are no Armigeres species.

Table-2: Mosquito Intensiveness with Man Bite Rate (MBR) in Mountain and Coastal Ecosystems in Luwu District in 2020

\begin{tabular}{|c|c|c|c|c|}
\hline \multicolumn{5}{|c|}{ Mountain Ecosystem } \\
\hline \multirow{2}{*}{ Mosquito Species } & \multicolumn{2}{|c|}{ Insider bait } & \multicolumn{2}{|c|}{ Outsider bait } \\
\hline & Number of species & MBR & Number of species & MBR \\
\hline Ae. Vexan & 0 & 0.00 & 3 & 0.09 \\
\hline An. Barbirostris & 9 & 0.27 & 5 & 0.15 \\
\hline An. Indefinitus & 0 & 0.00 & 1 & 0.03 \\
\hline An. Nigerrimus & 0 & 0.00 & 1 & 0.03 \\
\hline An. Vagus & 29 & 0.87 & 45 & 1.25 \\
\hline Ar. Malayi & 0 & 0.00 & 1 & 0.03 \\
\hline Cx. Bitaeniorhynchus & 1 & 0.03 & 1 & 0.03 \\
\hline Cx. Gelidus & 0 & 0.00 & 0 & 0.00 \\
\hline Cx. Nigropunctatus & 0 & 0.00 & 0 & 0.00 \\
\hline Cx. Pipiens group & 0 & 0.00 & 0 & 0.00 \\
\hline Cx. Quinquifasciatus & 4 & 0.12 & 5 & 0.14 \\
\hline Cx. Sitiens group & 1 & 0.03 & 1 & 0.03 \\
\hline Cx. Tritaeniorhynchus & 145 & 4.03 & 158 & 4.39 \\
\hline Cx. Vishnui & 3 & 0.08 & 4 & 0.11 \\
\hline Total & 192 & 6.19 & 225 & 6.81 \\
\hline \multicolumn{5}{|c|}{ Beach Ecosystem } \\
\hline \multirow{2}{*}{ Mosquito Species } & \multicolumn{2}{|c|}{ Insider bait } & \multicolumn{2}{|l|}{ Outsider bait } \\
\hline & Number of species & MBR & Number of species & MBR \\
\hline Ae. Vexan & 0 & 0.00 & 0 & 0.00 \\
\hline An. Barbirostris & 3 & 0.08 & 7 & 0.19 \\
\hline An. Vagus & 10 & 0.28 & 18 & 0.50 \\
\hline Cx. Bitaeniorhynchus & 0 & 0.00 & 0 & 0.00 \\
\hline Cx. Gelidus & 0 & 0.00 & 0 & 0.00 \\
\hline Cx. Nigropunctatus & 0 & 0.00 & 0 & 0.00 \\
\hline Cx. Quinquifasciatus & 1 & 0.03 & 1 & 0.03 \\
\hline Cx. Sitiens & 0 & 0.00 & 0 & 0.00 \\
\hline Cx. Sitiens group & 0 & 0.00 & 1 & 0.03 \\
\hline Cx. Tritaeniorhynchus & 125 & 3.47 & 223 & 6.19 \\
\hline Cx. Vishnui & 0 & 0.00 & 0 & 0.00 \\
\hline Total & 143 & 4.33 & 250 & 7.57 \\
\hline
\end{tabular}


Table 2 shows that in the mountainous and beach ecosystems the species that are more dominant to bite and are found in many species of Cx.Tritaeniorhynchus, where as a whole mountain ecosystem and beach ecosystem, the indoor bait has a lower mosquito density than the bait of people outside the house, where the bait for people in the house in the mountains ecosystem is 4.39 mosquito / person / night, the bait for people outside the house is 4.78 mosquito / person / night, while for the coastal ecosystem bait for the people in the house 3.78 mosquito / person / night and bait for people outside the house 6.75 mosquito / person / night.

\section{Effectiveness of Traps in Mountain Ecosystems}

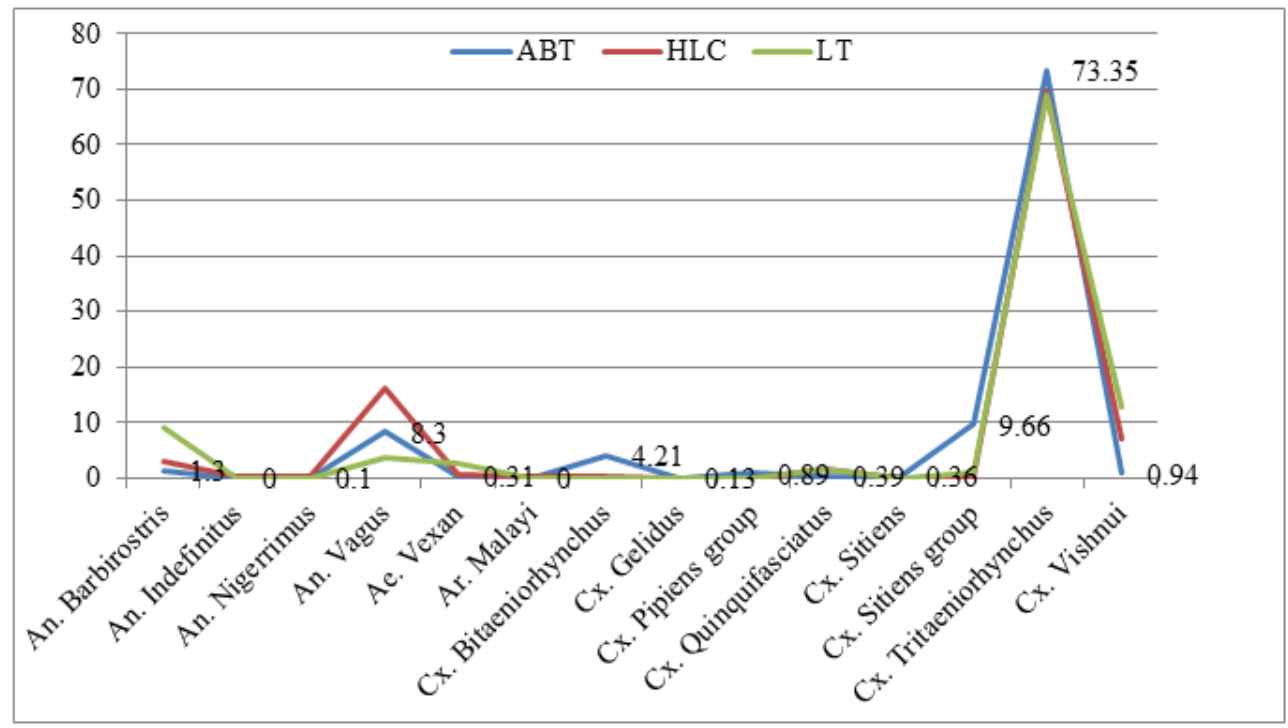

Graph-1: Percentage of Total Individuals Based on Trap Effectiveness in the Mountain Ecosystem of Luwu District in 2020

Graph 1 shows that based on the effectiveness of traps in mountains ecosystems using the Animal baited trap (ABT) method, there are 12 species, the most commonly caught species are Cx. Tritaeniorhynchus with a total of $73.35 \%$, Human landing collection (HLC) method of 11 species, the most caught species was Cx. Tritaeniorhynchus with a total of $69.50 \%$, Light trap method (LT) 7 species, the most caught species is Cx. Tritaeniorhynchus with an amount of $68.80 \%$.

\section{Effectiveness of Traps in Beach Ecosystems}

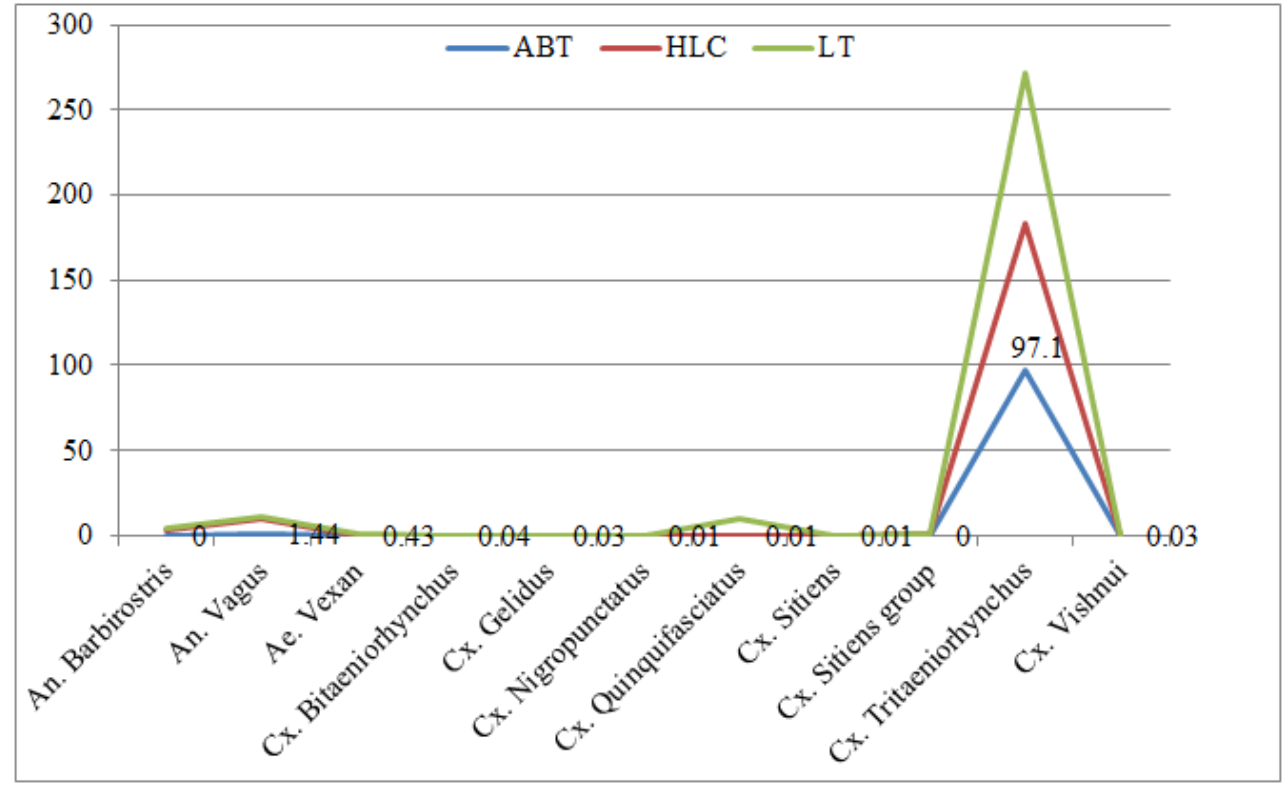

Graph-2: Percentage of Total Species Based on Trap Effectiveness in the Beach Ecosystem of Luwu District in 2020 
Graph 2 shows that based on the effectiveness of traps in the beach ecosystem using the Animal baited trap (ABT) method, 10 species were obtained, the most species being caught, namely Cx. Tritaeniorhynchus with a total of 97.1\%, Human landing collection (HLC) method of 6 species, the most caught species was Cx. Tritaeniorhynchus with a total of $86.70 \%$, the Light trap method (LT) 5 species, the most caught species is Cx. Tritaeniorhynchus with an amount of $87.78 \%$.

\section{Effectiveness of Traps in Mountain and Beach Ecosystems}

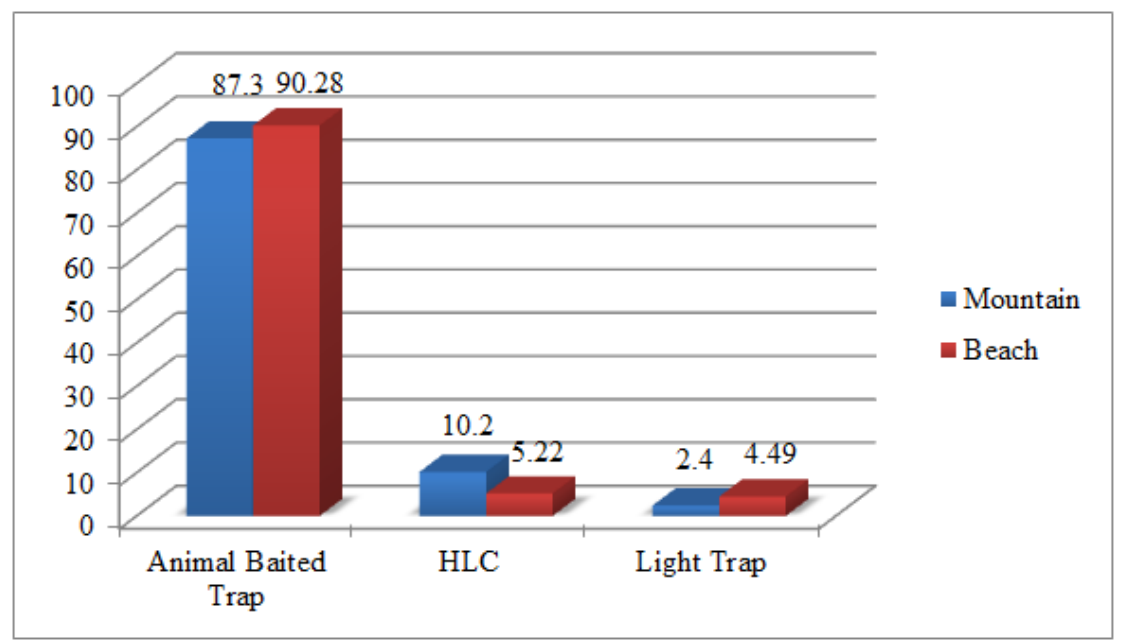

Graph-3: Percentage of Total Effectiveness of Traps in Mountain and Coastal Ecosystems of Luwu District in 2020

Graph 3 shows the percentage of trap effectiveness in mountains ecosystems of $87.3 \%$ using Animal baited traps $(\mathrm{ABT})$ and in beach ecosystems of $90.28 \%$ using Animal baited traps (ABT).

\section{DISCUSSION}

The discovery of mosquito fauna is influenced by several factors, generally rain accompanied by wind which affects the flight distance of the mosquito. Other factors, such as the geographical condition of nort Walenrang District as a mountains area, has a fairly large area of rice fields and plantations, some villages are close to mountains so that wind gusts affect the flight distance of mosquito. In Luwu District, high rainfall is one of the factors that influence the number of mosquito found. High rainfall also affects air humidity. Rain will increase the amount and type of standing water, which previously had little or no presence during the dry season, thereby increasing the likelihood of an aquatic cycle occurring in the mosquito life cycle. Rain accompanied by hot weather will increase the breeding of various types of mosquito [15].

In the mountains ecosystem, mosquito fauna was found including Anopheles spp 10.81\%, Aedes spp 0.41\%, Armigeres spp 0.02\%, Culex spp 88.74\%. Coastal ecosystems found Anopheles spp 96.77\%, Aedes spp 0.4\%, Culex spp 2.77\%. Culex spp and Anopheles spp are mostly found in mountainous and beach ecosystems. This is in line with the fauna research in Donggala District, that in the survey location An.barbirostris and An.vagus were found. The results of research in Halmahera are in line with this research, namely the An.vagus mosquito is found in both larva and adult rice fields with a salinity level of its habitat is 0.9 [7]. The mosquito species An.vagus and An.barbirostris are also found in rice fields and swamps in Kupang, East Nusa Tenggara. The next sequence was 1 mosquito An.subpictus (2\%). The results of this study indicate that there are differences in the diversity of Anopheles spp fauna, in different geographical conditions [9].

In the mountains ecosystem, the results of fishing at night using the Human landing collection (HLC) method obtained 11 species, namely An. Barbirostris, An.Indefinitus, An.Nigerrimus, An.Vagus, An.Vexan, Ar.Malayi, Cx.Bitaeniorhynchus, Cx. Quinquifasciatus, Cx. Tritaeniorhynhcus, Cx. Vishnui, Cx. Sitiens group. The Cx.Tritaenioryhncus species is the dominant species to suck blood throughout the night from 19: 00-05: 00, with peak densities between 19:00 and 02:00. The number of densities per person per hour outside the house is always higher than inside the house. The results of this study are in line with research conducted by Tangena et al. [19]. That the density of Cx.Tritaeniorhynchus actively sucks human blood with a density between 19: 00-02: 00 using the human landing collection method and is more active by baiting people outside the home.

The mosquito intensiveness with Man bite rate (MBR) with human bait was obtained 6 species, namely, An.Barbirostris, An.Vagus, Cx.Quinquifasciatus, Cx.Sitiens group, Cx.Tritaeniorhyncus, Cx.Vishnui. The dominant 
species biting / sucking human blood using the Human landing collection (HLC) method in the coastal ecosystem of species Cx. Tritaeniorhyncus where the density occurred at 19:00 - 01:00 and at high humidity Cx. Tritaeniorynchus was more active biting. The optimal temperature that can affect the development of mosquito is $20-30{ }^{\circ} \mathrm{C}$. The humidity in the study area is $58-95 \%$ and is the optimal humidity for mosquito to breed. Air humidity is a determinant of the mosquito lifespan. A similar study was conducted by which stated that research conducted on the coast with the dominant Human landing collection found the species Cx Tritaenioryhnchus.

Research conducted in mountains ecosystems in the district of North Walenrang, namely the villages of Siteba, Limbong and Sangtandung in 14 species of mountain ecosystems found, namely 19 Ae.Veksan, 1 Ar.Malayi, 163 Cx. Bitaeniorhyncus, 5 Cx.Gellidus, 1 Cx .Nigropunctatus, 372 Cx. Pipiens group, 390 Cx.Quinquifasciatus, 401 Cx.Sitiens group and $44 \mathrm{Cx}$. Vishnui. Anopheles spp, namely 78 An.Barbirotris, 1 An.Nigerrimus, 398 An.Vagus, the most dominant species in this study was Cx.Tritaeniorhynhcus, this species likes habitats inside and outside the house, cold, or floating with direct sunlight and little. Shade Culex tritaeniorynchus is more common at night. According to Nepomichene et al. this species is active at night with the highest activity peak at 21.00 and 02.30 .

The behavior and habitat of Cx.Tritaeniorhynchus lives in dirty environments such as rice fields, waterways, wells, streams or rivers, low salinity, trenches, and polluted water bodies. According to Nikookar et al. [13], this species also lives in trenches, and stagnant water from sewage and for toilet purposes (bathing, washing, and latrines), open swamps, and watersheds which are potential habitats for $\mathrm{Cx}$. Tritaeniorhyncus.

In the coastal ecosystem, precisely in Bonepute Village, Tembo'e Village and Babang Village, North Walenrang Sub-District, eleven species were found, namely 26 species An.Veksan, 3 Cx. Bitaeniorhyncus, Cx.Gelidus, 1 Nigropunctatus, 2 Cx.Quinquifasciatu, 6 Cx Sitiens group, 6,480 Cx. Tritaeniorhynchus, 2 Cx. Vishnui. Anopheles spp, 87 An. Barbirostris, 1 An. Indefinitus, 4 An. Nigerrimus. Of the nine species that are routinely found during fishing, they are Cx. Bitaeniorhyncus and Cx. Tritaeniorhyncus. In the beach ecosystem the most dominating and the most densely populated is the Cx.Tritaeniorhyncus mosquito because in the location around the coast there are many swamps near the ponds and puddles of water that are inundated by fishermen's shrimp ponds, waterways and rice fields.

The results of this study are in accordance with the results of a survey conducted Windiastuti [22]. Regarding population density and habitat preferences for mosquito in various ecosystems in Pekalongan District. The results of catching mosquito in five locations were obtained by 14 species of mosquitoes from three genera, namely, Aedes which consists of four species, Anopheles six species, and Culex four species. Two species were found at all locations namely, Ae.Vexan and Cx.Vishnui. Environmental factors that influence the mosquito population include the availability of mosquito breeding sites. Environmental factors where mosquitoes breed such as the presence or absence of vegetation and water quality affect the types of mosquito species that can live in it [18]. In the area of Luwu Regency, it has quite a large area of rice fields and plantations, the presence of vegetation greatly influences the life and density of mosquitoes, as a place to lay eggs, shelter, find food and shelter for larvae and shelter for adult mosquito while waiting for the gonotropic cycle. In addition, the presence of various types of plants in one place can be used as an indicator to predict the presence of certain types of mosquito.

\section{CONCLusions}

Mosquito biodiversity found in mountains ecosystems consists of four genera, namely Anopheles spp, Aedes spp, Armigeres spp, Culex spp and in coastal ecosystem three genera Anopheles spp, Aedes spp, and Culex spp. Mosquito density with Man bite rate (MBR) in mountain ecosystems and beach ecosystems with more dominant biting species and many species of Cx.Tritaeniorhynchus, where overall the mountain ecosystem and the beach ecosystem of indoor baiting have lower mosquito density than bait. people outside the house where the bait for people inside the house in the mountain ecosystem is 4.39 mosquito / person / night, the bait for people outside the house is 4.78 mosquito / person / night, while for the beach ecosystem bait for people in the house 3.78 mosquito / person / night and person outside the house 6.75 mosquito / person / night.

The individual differences obtained based on the effectiveness of the trap are more and more diverse species found in mountainous ecosystems than in beach ecosystems. In the mountain ecosystem Animal baited trap (ABT) obtained 12 species, total ABT species 87.30, Human landing collection (HLC) 11 species, total HLC species 10.20\%, Light trap (LT) 7 species, total LT 2 species, 49\%. While individuals obtained based on the effectiveness of traps in beach ecosystems, Animal baited trap (ABT) obtained 10 species, total ABT species 90.28 Human landing collection (HLC) 6 species, total HLC species 5.22\%, Light trap (LT) 5 species, total species LT $4.49 \%$. 


\section{REFERENCES}

1. Bai, L., Morton, L. C., \& Liu, Q. (2013). Climate Change and Mosquitoborne Diseases in China: A.Review, Globalization and Health, https://doi.org/doi: 10.1186/17448603910.

2. Elyazar, I.R.F., Sinka, M.E., Gething, P.W., Tarmidzi, S. N., Surya, A., Kusriastuti, R., \& Bangs,M. J. (2013). The distribution and bionomics of Anopheles malaria vector mosquitoes in Indonesia. Advances in Parasitology. Elsevier, 1(83):280-288.

3. Guo, S., Ling, F., Hou, J., Wang, J., Fu, G., \& Gong, Z. (2014). Mosquito Surveillance Revealed Lagged Effects of Mosquito Abundance on Mosquito-Borne Disease Transmission: A Retrospective Study in Zhejiang, China. Plos One, 9(11):223-231.

4. Ishak, H., \& Abd. Hakim, B.H. (2015). Effect of ovitrap modification and attractant substances to the mosquito Aedes Sp density base on the endemicity in Makassar City. International Journal of Sciences: Basic and Applied Reseacrh (IJSBAR), 24(3):236-243.

5. Janko, M.M., Irish, S.R., Reich, B. J., Peterson, M., Doctor, S.M., Mwandagalirwa, M.K., Emch, M.E. (2018). The Links Between Agriculture, Anopheles Mosquitoes, and Malaria Risk in Children Younger than 5 Years in the Democratic Republic of the Congo: a Population-Based, Cross-Sectional, Spatial Study. The Lancet Planetary Health, 2(2):128-136.

6. Kemenkes, R.I. (2014). Peraturan Menteri Kesehatan Republik Indonesia Nomor 45 Tahun 2014. Indonesia : Kementrian Kesehatan Republik Indonesia

7. Lvov, D.K., Shchelkanov, M.Y., Alkhovsky, S.V., \& Deryabin, P.G. (2015). Single-Stranded RNA Viruses. Zoonotic Viruses in Northern Eurasia. https://doi.org/10.1016/b978-0-12-801742-5.00008-8

8. Mayer, S.V., Tesh, R.B., \& Vasilakis, N. (2017). The Emergence of Arthropod-Borne Viral Diseases: A Global Prospective on Dengue, Chikungunya and Zika Fevers. Acta Tropica, 16(6):155-163.

9. Moiroux, N., Gomez, M.B., Pennetier, C., Elanga E., Djènontin, A., Chandre, F., Corbel, V. (2012). Changes in Anopheles Funestus Biting Behavior Following Universal Coverage of Long-Lasting Insecticidal Nets in Benin, The Journal of Infectious Diseases, 20(6):26-33.

10. Munif, A. (2009). Nyamuk Vektor Malaria dan Hubungannya dengan Aktivitas Kehidupan Manusia di Indonesia. Journal of Vector Borne Diseases Studies, 1(2):94-102.

11. Mzilahowa T., Luka B.M., Uzalili V., Mathanga D.P., Campbell C.H., Mukaka M. \& Gimnig J.E. (2016). Risk Factors For Anopheles Mosquitoes in Rural and Urban Areas of Blantyre District, Southern Malawi. Malawi Medical Journal, 28(4):151-158.

12. Nepomichene T.N.J.J., Elissa N., Cardinale E., \& Boyer S. (2015). Species Diversity, Abundance, and Host Preferences of Mosquitoes (Diptera: Culicidae) in Two Different Ecotypes of Madagascar with Recent RVFV Transmission. Journal of Medical Entomology, 52(5):962-969.

13. Nikookar S.H., Fazeli-Dinan M., Azari-Hamidian S., Nasab S.N.M., Aarabi M., Ziapour S.P., Hemingway J. (2018). Fauna, Ecological Characteristics and Checklist of the Mosquitoes in Mazandaran Province, Northern Iran. Journal of Medical Entomology, 55(3);1-12.

14. Pelletier, J., \& Leal W.S. (2017). Characterization of Olfactory Genes in the Antennae of the Southern House Mosquito, Culex quinquefasciatus. Journal of Insect Physiology, 57(7): 915-929.

15. Radrova, J., Seblova, V., \& Votypka, J. (2013). Feeding Behavior and Spatial Distribution of Culex Mosquitoes (Diptera: Culicidae) in Wetland Areas of the Czech Republic. Journal of Medical Entomology, 50(5):1097-1104.

16. Rowley, A.F. (2016). 'The Potential Impact of Climate Change on the Infectious Diseases of Commercially Important Shellfish Populations in the Irish Sea - A Review', ICES Journal of Marine Science: Journal du Conseil, 73;51-69.

17. Sallam M.F., Al Ahmed A.M., Abdel D.M.S., \& Abdullah M.A.R. (2013). Ecological Niche Modeling and Land Cover Risk Areas for Rift Valley Fever Vector, Culex tritaeniorhynchus Giles in Jazan, Saudi Arabia. Plos One, 8(6):19-22.

18. Tanm, S., \& Hadi U.K. (2019). Ragam Spesies dan Karakteristik Habitat Nyamuk di Kecamatan Juai, Kabupaten Balangan, Provinsi Kalimantan Selatan, 11(1):19-28.

19. Tangena J.A.A., Thammavong P., Hiscox A., Lindsay S.W. \& Brey P.T. (2015). The Human-Baited Double Net Trap: An Alternative to Human Landing Catches for Collecting Outdoor Biting Mosquitoes in Lao PDR. PLoS ONE, 10(9):1-13.

20. Torres C.O.M., Baak C.M., Cigarroa T.N., Zaragoza V.C. V., Arjona J.G., Moreno P.L.G., Garcia R.J.E. (2017). Mosquito Fauna in Home Environments of Tabasco, Mexico. Southwestern Entomologist, 42(4):969-982.

21. WHO. (2003). 'Climate Change and Infectious Diseases. Climate Change and Human Health: Risks and Responses', World Health Organization, 103-37. https://doi.org/10.2307/2137486.

22. Windiastuti, I.A. (2016). Hubungan Kondisi Lingkungan Rumah, Sosial Ekonomi dan Perilaku Masyarakat dengan Kejadian Filariasis di Kecamatan Pekalongan Selatan Kota Pekalongan The Association between Environmental House Condistion, Socio-economic, and Behaviour Factors with fi, 12(1). 